\title{
A third era of credit theory? Endogenous money from Wolfgang Stützel's balance mechanics perspective*
}

\author{
Christoph Ellermann \\ European Central Bank, Frankfurt, Germany \\ Fabian Lindner \\ Macroeconomic Policy Institute (IMK), Düsseldorf, Germany \\ Severin Reissl \\ Kingston University, Kingston upon Thames, United Kingdom \\ Ruben Tarne** \\ Berlin
}

We present an introduction to the translation of a part of the stock-flow consistent (SFC) framework published by the German economist Wolfgang Stützel in 1958, which follows in this issue. While not a quantitative model, Stützel's 'balance mechanics' has some features which still stand out today when compared with contemporary SFC literature. Among these strengths is an accounting decomposition of all economic transactions along three dimensions and a careful distinction between propositions which are true at different levels of aggregation, so as to avoid fallacies of composition. We argue that 'balance mechanics' provides value added, both as a didactic tool and as a complement to formal SFC modelling exercises, since it can be used to assess the validity and coherence of economic propositions. We demonstrate this claim by translating a section on the so-called 'third stage of credit theory' in the translation that follows this introductory paper. Therein, Stützel synthesises the two opposing positions in the controversy on the causal priority of deposits versus loans in banking.

Keywords: Stützel, balance mechanics, endogenous money, stock-flow consistency

JEL codes: $B 31, B 41, B 50, E 51$

\section{INTRODUCTION: ON THE RELEVANCE OF WOLFGANG STÜTZEL'S BALANCE MECHANICS}

In his two major works (Stützel 1958 [1978]; 1953 [1979]), the German economist Wolfgang Stützel (1925-1987) develops a framework for systematically thinking about monetary economies whilst avoiding fallacies of composition. Characteristic of his

\footnotetext{
* This article represents the views of the authors and not necessarily those of the institutions represented.

** Corresponding author: email: ruben.tarne@gmail.com.
}

Received 26 December 2016, accepted 4 January 2017 
approach is to highlight the logical relationships that exist between nominal magnitudes in any economy and which must hold by accounting necessity. Despite their trivial nature, these relationships are, in Stützel's opinion, all too often neglected in economic analysis, leading to the adoption of implicit but unrealistic assumptions, flawed accounting, or fallacies of composition. By setting out these relationships using a terminologically clear distinction between general categories of stocks and flows and developing a methodology for using them to analyse economic issues, Stützel became an early exponent of what was later termed stock-flow consistent analysis.

The currently blossoming literature on stock-flow consistent (SFC) modelling mostly builds on the work of Godley/Lavoie (2007), a book which has become a standard methodological reference for the SFC approach (see Caverzasi/Godin 2014 for a review of this literature). One potential drawback of Godley/Lavoie's approach is that SFC modelling as commonly practised almost exclusively focuses on the behaviour of aggregated sectors (Toporowski/Michell 2012). Intra-sectoral developments are often left out of the picture, although there is currently a trend toward the introduction of agent-based elements into SFC macroeconomic models to allow for an examination of intra-sectoral dynamics (for example, Caiani et al. 2016; Michell 2014a).

We argue that Stützel's method, which we present in this introductory article and which is largely unknown in the contemporary English-speaking literature, can serve as a complement to these approaches. Rather than developing a quantitative modelling method, Stützel proposes a framework which is based on simple accounting relationships and the division of particular totalities of economic units into groups (subsets) as required for the task at hand, without relying on rigid divisions of economies into particular sectors. From these foundations one can then derive generally valid sets of statements arising from the accounting framework, or work through example cases based on (non-formalised) behavioural assumptions to evaluate their plausibility. This way of using an SFC method bears some similarity to that advocated by Michell (2014b), who argues that the use of a stock-flow consistent accounting framework can by itself (that is, without the imposition of rigid behavioural rules as in formal modelling) be useful to address particular questions. Later in the translation that follows this introductory paper, we provide an illustration of Stützel's method by translating a passage from one of his books which discusses the relationships between stocks and flows of bank credit and between the asset and liability sides of banks' balance sheets. In that section, Stützel reconciles what he calls the first and the second stages of credit theory. The controversy about whether banks must attract deposits before they can lend (Blanchard/Johnson 2013: ch. 4; Humphrey 1982; 1988) or whether 'loans make deposits' (for example, Kaldor 1982; Moore 1983) is resolved through integrating both propositions into a more general view. This is particularly interesting given the deadlock in the debate between advocates of the money multiplier theory of bank credit and their post-Keynesian critics. Stützel's framework shows how these views can be synthesised to get a realistic picture that allows for a proper interpretation of statistics on the volume of bank credit.

In this introductory paper, we provide some historical background of Stützel's work in Section 2.1, introduce some key concepts of balance mechanics in Section 2.2, and indicate some recent literature using the approach in Section 3. ${ }^{1}$ Section 4 concludes.

1. All of the present authors have applied the balance mechanics method to specific problems, see Ellermann (2015), Lindner (2015a; 2015b), Reissl (2015) and Tarne (2016). 


\section{BALANCE MECHANICS}

In briefly outlining the basics of balance mechanics, we hope to show that in certain ways, Stützel's approach is both more general and more specific than post-Keynesian stock-flow consistent modelling as presented, for instance, by Godley/Lavoie (2007). It is more general since it focuses on concepts common to any kind of economic unit, be they households, governments, banks or firms. It is more specific since its typology of general categories of flows is more finely differentiated. Specifically, apart from distinguishing current-account transactions and pure financial transactions, it also introduces a clear distinction between production and consumption, on the one hand, and revenues and expenditures, on the other. It is, however, of course still fully compatible with SFC modelling and in our view close to post-Keynesian thought in general, as can also be discerned from the historical background of Stützel's work.

\subsection{Historical background}

Stützel did not develop his framework in isolation. In Germany, practitioners such as Lautenbach (for example, Lautenbach 1952), who worked at the German economics ministry from the 1920s until 1934 and who would become Stützel's teacher and main influence, as well as theorists such as Föhl (1937), had been working to develop a novel way of macroeconomic thinking. Like Keynes in the Treatise on Money (1930), these economists were strongly influenced by 'German credit theory' and credit mechanics as pioneered by Wicksell (1898 [1936]), and further developed by Hahn (1920 [2015]). Furthermore, they were working at a time when historical developments such as the Great Depression, tendencies of national economies to isolate themselves into closed 'trade empires', and the German reparation problem both necessitated and facilitated the recognition of macroeconomic accounting relations and their implications. This new way of thinking found its clearest expression in the novel method of analysing closed credit systems (for example, Lautenbach 1952: ch. 1, sec. 3 and ch. 2), and many of the analytical categories of what would become Stützel's balance mechanics originate from there.

The German credit theorists developed their economic ideas in parallel with Keynes. ${ }^{2}$ It is thus unsurprising that Stützel's ideas have much in common with those of Keynes, particularly a focus on the relationship between microeconomic and macroeconomic propositions, and the emphasis on possible fallacies of composition and macroeconomic paradoxes. Furthermore, Stützel's work shares some resemblance with that of other authors who were influenced by German credit theory, one of whom is Kalecki, who shares with Stützel the notion of self-financing investment (cf. Kalecki 1971: 13; Stützel 1958 [1978]: 254, fn 1).

While Stützel was at one point well-known in Germany, serving on the Council of Economic Advisors for one year, his name is virtually unknown in the English-speaking literature. Following a dismissive review of Economic Balance Mechanics in the American Economic Review (Hein 1959), his work does not appear to have attracted any further attention. In Germany, interest in his work has resurged during periods of crisis, as evidenced by the re-publication of his two major works in the 1970s, as well as by the reprint

2. Indeed, Kindleberger (1996: 164) calls Lautenbach the 'German Keynes before Keynes'. Hagemann $(2008 ; 2014)$ provides a discussion of the German pre-Keynesian 'Keynesians' and their relationship with Keynes. 
of Stützel (1958 [1978]) in 2011. Section 3 will point to some recent publications drawing on Stützel's approach.

\subsection{Key elements of balance mechanics}

Stützel conceives of the economy as a set of economic agents (units) who are connected through their balance sheets, focusing on those relationships between economic agents that must hold by logical necessity. The first key element of balance mechanics is Stützel's typology of different aggregates of economic units:

- A totality can be the aggregate of all economic units in existence (that is, a closed national economy, or the world economy), or it can be the entire set of all economic units of a certain type (for example, all firms or all banks), depending on the task at hand.

- A group is a genuine subset of a given totality, the elements of which will usually share a common characteristic. For any group, there exists a complementary group which contains all other elements of the given totality. For instance, we may, as Stützel does in the translated section that follows this introcutory paper, divide the totality of all non-banks into the group of all net bank creditors and the complementary group of all net bank debtors. Taking the world economy as the given totality, the complementary group to a single national economy would be the rest of the world. Note that a group can also be an individual economic unit, the complementary group being all other economic units.

Based on the division of a given totality of economic units into a group and a complementary group, Stützel is able to derive sets of generally valid statements about the relationships between the given totality, the group, and the complementary group at hand. Global statements are statements pertaining to the totality (for example, an economy), while partial statements refer to a group (for example, all households). Generally, the application of a partial statement to the totality constitutes a fallacy of composition. Finally, relational statements describe the behaviour of the complementary group (for example, all non-households) which is necessary for a partial statement to be valid for a given group. Our translation contains examples of this approach, and it is also applied in some of the contributions we survey in Section 3.

The second element of balance mechanics consists of fundamental accounting relationships. A careful distinction between stocks and flows lies at the heart of Stützel's framework, with the difference between flows into and out of a stock (that is, the balance) giving rise to changes in that stock. A critical concept in Stützel's approach is the idea of lockstep. If flows into and out of a stock over a given period are of equal size, the inflows and outflows are said to move in lockstep. If in- and outflows move in lockstep, the stock in question remains constant, regardless of how much these flows may fluctuate. ${ }^{3}$

One of the advantages of Stützel's approach is that he builds on standard German accounting concepts (see Kaiser 2008 for an introduction). Stützel's contribution consists of applying widely used concepts from business accounting to questions of economic theory. As will be shown below, there exists a finer terminological distinction between different transaction flows in the German accounting tradition than in Anglo-Saxon accounting.

3. While this may seem trivial, Stützel (1958 [1978]) uses this insight to draw up a broad critique of Walras's general equilibrium framework and its key assumptions (see below). 


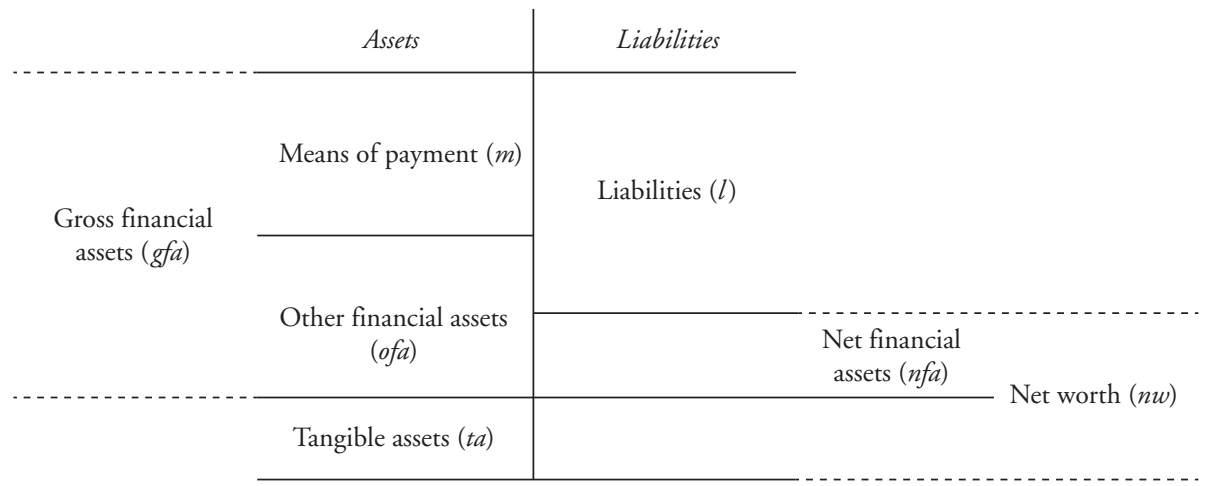

Source: Translated from Grass/Stützel (1988: 53).

Figure 1 Balance sheet

The balance sheet of any economic unit measures all stocks held by that unit at a given point in time and consists of tangible assets, (gross) financial assets, and liabilities, as shown in Figure 1.

The difference between a unit's total assets and liabilities are its net worth $(n w)$. Importantly, net financial assets $(n f a)$ are defined as the difference between gross financial assets $(g f a)$ and liabilities $(l)$. Decomposing financial assets into 'means of payment' $(m)$ and other financial assets (ofa), this yields the following identity:

$$
n f a=(m+o f a)-l .
$$

Notably, in a system in which credit exists, changes in net financial assets and changes in the stock of means of payment are governed by quite distinct relations. Since every financial asset has a corresponding liability, the sum of $n f a$ of all economic units is necessarily equal to zero. ${ }^{4}$ This strict arithmetic relationship allows the setting up of the following set of statements:

Partial statement: An individual economic unit or a group of units can increase its net financial assets through running expenditures which are smaller than its revenues.

Relational statement: An individual economic unit or group of units can only increase its net financial assets through running expenditures which are smaller than its revenues if and to the extent that its complementary group (all other economic units) achieves or incurs the reciprocal decrease in $n f a$.

Global statement: The entirety of all units in a closed (world) economy can neither increase nor decrease its net financial assets. The sum of all (changes in) $n f a$ in the world economy is always equal to zero. ${ }^{5}$

In contrast to net financial assets, no clear-cut definition of 'means of payment' can be given. What constitutes a means of payment is largely context-dependent, specific for

4. This holds in a closed (or world) economy without monetised metals.

5. Given his analysis based on these considerations, Stützel (or even Lautenbach before him) can be viewed as the originator of the so-called 'fundamental identity' (Lavoie 2014: 259ff), which has variously been attributed to Godley or Tobin. 
example to the recipient of the payment. For non-banks, bank sight deposits usually serve as means of payment. Banks, however, regularly only accept balances with the central bank as means of payment among themselves. For international transactions, finally, the choice of a means of payment is typically even more restricted, for example to gold, or bank deposits in certain currencies.

Moving on to flows that can give rise to changes in these stocks, Stützel proceeds to categorise all transactions along three dimensions, shown in Figure 2 below. This figure shows the three types of transactions (flows) which exist in Stützel's framework, and (reading from left to right) the changes in the stocks to which balances in these flows give rise. The figure also indicates that the different types of transactions often coincide, but that this is not necessarily the case, which is why the cells only partly overlap.

- Revenues and expenditures are transactions which give rise to changes in a unit's net financial assets. They are also termed transactions on current account, ${ }^{6}$ and include wages, purchases and sales of goods, donations or interest expenses. By contrast, pure financial transactions are transactions which lead to an equal increase (or decrease) in the financial assets and liabilities of a unit and hence are neutral with respect to $n f a$. If a unit's revenues exceed its expenditures during a given period, it is said to run a 'revenue surplus' and its net financial assets increase. Stützel also frequently refers to such an increase in $n f a$ as 'financial saving'. Conversely, if its expenditures exceed its revenues, a unit is running an 'expenditure surplus'.

- Payments and receipts are flows which change a unit's stock of means of payment.

- Finally, income and consumption are flows which change a unit's net worth. For instance, the consumption of a good which is already owned by a unit has no impact on its $n f a$ or $m$ at that moment in time, but changes its net worth. In line with the Haig-Simons definition of income (Godley/Lavoie 2007: 140), saving is defined as the change in net worth.

Of course, these types of transactions will often coincide, as is also indicated by Figure 2. For instance, a transaction on current account, giving rise to a revenue and an expenditure, will often coincide with a receipt and a payment (for example, the sale of a good for cash or in exchange for a bank sight deposit). However, there are also important instances in which these transactions do not coincide, meaning that the distinction is important to provide for consistent accounting. For example, the sale of a good on credit gives rise to a revenue

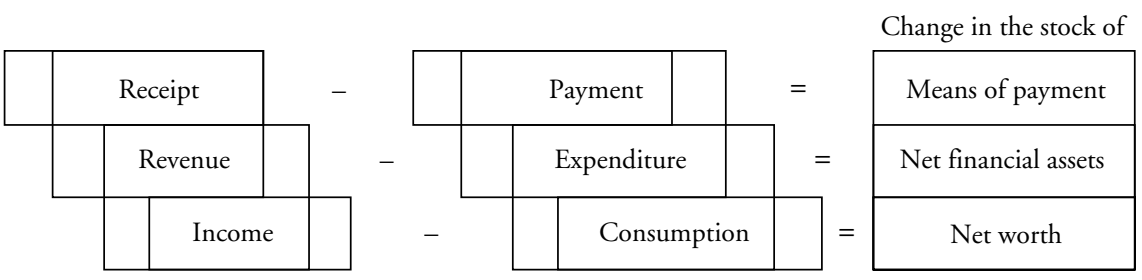

Source: Adapted and translated from Grass/Stützel (1988: 55).

Figure 2 Three types of transactions

6. Asset revaluations also give rise to changes in $n f a$, but Stützel does not consider these in his work. 
and an expenditure, but the stocks of means of payment held by the parties do not change. Similarly, payments and receipts do not necessarily coincide with revenues and expenditures. For instance, the purchase of a financial asset in exchange for means of payment, considered by itself (that is, abstracting from any changes in the price of the asset), does not give rise to revenues or expenditures and does not alter the $n f a$ of the involved parties.

The revenue-expenditure nexus and the payment-receipt nexus can be gainfully combined. Defining net liabilities $(n l)$ as $n l=l-o f a$, we can rearrange equation (1) to get:

$$
m=n f a+n l \text {. }
$$

Taking first differences with respect to time, this identity is familiar from the international balance of payments where $\Delta m$ is the balance on international reserve account, $\Delta n f a$ the balance on current account, and $\Delta n l$ the balance on the (narrowly defined) capital account. The relations between changes in the three stocks can be illustrated by three limiting cases:

- If over a given period all transactions on current account (that is, those giving rise to revenues or expenditures) are settled in cash and there are no other transactions whatsoever, then for each individual unit $\Delta m=\Delta n f a$.

- If $\Delta m=0$ for all economic units over a given period, then $\Delta n f a=-\Delta n l$ for all units. This case is termed 'constant liquidity' or, drawing on one of our earlier definitions, 'payment-receipt lockstep'.

- If each individual economic unit's expenditures are equal to its revenues over a given period $(\Delta n f a=0)$, then the change in any unit's holdings of means of payments equals the change in its net liabilities. This case is termed 'revenue-expenditure lockstep'.

As Stützel argues at length in his Paradoxes (1953 [1979]: ch. 3), the last case is of special interest for the critique of Walras's general equilibrium model. Stützel shows that Walras develops his theory as a model of pure revenue-expenditure lockstep, thereby abstracting from credit - a constitutive feature of the economy, eventually leading him to conflate the distinct concepts of lockstep and 'equilibrium'.

\section{SCOPE OF APPLICATION}

Stützel's framework lends itself to the analysis of a wide range of economic phenomena that have been discussed particularly in the aftermath of the global financial crisis. For instance, balance mechanics offers an innovative angle on the saving-investment nexus, as well as on liquidity preference and interest-rate determination, as has been shown by Lindner (2015a; 2015b). In a global context, the controversy about the 'global saving glut' hypothesis (Bernanke 2005) has attracted much attention, and would have benefited from a more thorough understanding of balance mechanic relationships, which has been advocated in this context either explicitly (Lindner 2015a) or implicitly (Borio/Disyatat 2011). In a European context, a similar controversy arose around TARGET2 balances and their implications for domestic bank credit in creditor countries (Bindseil/König 2011; Sinn/Wollmershäuser 2012). This debate has similarly been addressed from a balance mechanics perspective (Horn/Lindner 2011), clearly showing the flawed accounting on which the arguments of advocates of the 'capital exports hypothesis' are based. Any of the explicit applications of balance mechanics to contemporary problems outlined above represent a good starting point to learn about the method in more detail. In addition, general discussions of Stützel's work and its relevance can be found in Flassbeck (2001) and Schmidt $(2011 ; 2012)$. In one of the few existing English contributions (alongside 
Lindner 2015a; 2015b; and Reissl 2015), Schmidt (forthcoming) shows the value of balance mechanics as a didactic tool, pointing out the flaws of commonly used textbooks. While there is thus a growing literature applying the balance mechanics approach, we nevertheless believe that it is worth having a look at Stützel's original work, both to make a wider audience aware of his contribution and to possibly pave the way for a more extensive translation project in the future.

The section we translate in the paper that follows this introduction is taken from Stützel (1958 [1978]), more specifically pages 208 to 219. This section has been chosen for multiple reasons. It is one of the few discussions in Stützel's books which are relatively self-contained and can thus be presented on its own with relatively little context. At the same time, we believe the section to be highly relevant in that it presents an interesting resolution of the debate between what Stützel calls the 'orthodox' and 'modern' theories of bank credit and establishes some seemingly trivial but important accounting relationships which any exercise in monetary economics should keep in mind. It is also interesting because of Stützel's discussion of the reflux mechanism which has also been a subject of debate among post-Keynesian authors (Arestis/Howells 1996; Lavoie 1999; Ramanan/Rochon 2015). Hence, we believe that this section will be of interest to many readers.

\section{CONCLUSION}

To conclude, we hope that through the general introduction to balance mechanics as well as through our translation of a section of Stützel's own work we are able to demonstrate that the balance mechanics approach should be of great interest to anyone interested in issues of stock-flow consistency and macroeconomic analysis more generally. In our view, Stützel's approach provides value-added whenever balances are at the heart of an economic phenomenon. It thus possesses an enormous potential scope of application. Additionally, for all of the present authors, balance mechanics has proved to be of great didactic value in learning to think through economic issues in a consistent fashion, a skill which should be central to any economics education but which today is all too often neglected.

\section{REFERENCES}

Arestis, P., Howells, P. (1996): Theoretical reflections on endogenous money: the problem with 'convenience lending', in: Cambridge Journal of Economics, 20(5), 539-551.

Bernanke, B. (2005): The global saving glut and the U.S. current account deficit, Sandridge Lecture, Virginia Association of Economists, Richmond, Virginia, 10 March, URL: https://www. federalreserve.gov/boarddocs/speeches/2005/200503102/.

Bindseil, U., König, P.J. (2011): The economics of TARGET2 balances, SFB 649 Discussion Paper No 2011-035.

Blanchard, O., Johonson, D. (2013): Macroeconomics, 6th edn, Harlow, UK: Pearson.

Borio, C., Disyatat, P. (2011): Global imbalances and the financial crisis: link or no link?, BIS Working Paper No 346.

Caiani, A., Godin, A., Caverzasi, E., Gallegati, M., Kinsella, S., Stiglitz, J. (2016): Agent-based stock-flow consistent macroeconomics: towards a benchmark model, in: Journal of Economic Dynamics and Control, 69, 375-408.

Caverzasi, E., Godin, A. (2014): Post-Keynesian stock-flow-consistent modelling: a survey, in: Cambridge Journal of Economics, 39(1), 157-187.

Ellermann, C. (2015): The problem of wholesale bank funding in stock-flow consistent analysis, Master thesis submitted to the School of Oriental and African Studies, University of London. 
Flassbeck, H. (2001): Gesamtwirtschaftliche Paradoxa und Moderne Wirtschaftspolitik: Wolfgang Stützels Beitrag zu einer rationalen Ökonomie, in: Keztel, E., Prigge, S., Schmidt, H. (eds), Wolfgang Stützel: Moderne Konzepte für Finanzmärkte, Beschäftigung und Wirtschaftsverfassung, Tübingen, Germany: Mohr Siebeck, 409-426.

Föhl, C. (1937): Geldschöpfung und Wirtschaftskreislauf, Munich and Leipzig, Germany: Duncker \& Humblot.

Godley, W., Lavoie, M. (2007): Monetary Economics: An Integrated Approach to Credit, Money, Income, Production and Wealth, Basingstoke, UK: Palgrave Macmillan.

Grass, R.-D., Stützel, W. (1988): Volkswirtschaftslehre, 2nd edn, Munich: Vahlen.

Hagemann, H. (2008): Zur frühen Rezeption der General Theory durch deutschsprachige Wirtschaftswissenschaftler, in: Hagemann, H., Horn, G., Krupp, H.J. (eds), Aus gesamtwirtschaftlicher Sicht: Festschrift für Jürgen Kromphardt, Marburg, Germany: Metropolis, 71-104.

Hagemann, H. (2014): L. Albert Hahn's economic theory of bank credit, in: Journal of Post Keynesian Economics, 37(2), 309-335.

Hahn, A. (1920 [2015]): Economic Theory of Bank Credit, Oxford: Oxford University Press.

Hein, J. (1959): Review of W. Stützel: Volkswirtschaftliche Saldenmechanik: Ein Beitrag zur Geldtheorie, in: American Economic Review, 49(5), 1088-1089.

Horn, G., Lindner, F. (2011): Kein Kapitalabfluss aus Deutschland: Eine Fundamentalkritik an Hans-Werner Sinns Kapitalexport-These, IMK Policy Brief, May.

Humphrey, T. (1982): The real bills doctrine, in: Federal Reserve Bank of Richmond Economic Review, 68(5), 3-13.

Humphrey, T. (1988): Rival notions of money, in: Federal Reserve Bank of Richmond Economic Review, 74(5), 3-9.

Kaiser, D. (2008): Treasury Management: Betriebswirtschaftliche Grundlagen der Finanzierung, Wiesbaden, Germany: Gabler Verlag.

Kaldor, N. (1982): The Scourge of Monetarism, Oxford: Oxford University Press.

Kalecki, M. (1971): Selected Essays on the Dynamics of the Capitalist Economy, Cambridge, UK: Cambridge University Press.

Keynes, J.M. (1930): A Treatise on Money, Vol. II: The Applied Theory of Money, Moggridge, D., Johnson, E. (eds), The Collected Writings of John Maynard Keynes, Volume XI, Cambridge, UK: Macmillan and Cambridge University Press.

Kindleberger, C. (1996): World Economic Primacy: 1500-1990, Oxford: Oxford University Press.

Lautenbach, W. (1952): Zins, Kredit und Produktion, Tübingen, Germany: Mohr Siebeck.

Lavoie, M. (1999): The credit-led supply of deposits and the demand for money: Kaldor's reflux mechanism as previously endorsed by Joan Robinson, in: Cambridge Journal of Economics, 23(1), 103-114.

Lavoie, M. (2014): Post-Keynesian Economics: New Foundations, Cheltenham, UK and Northampton, MA: Edward Elgar.

Lindner, F. (2015a): Did scarce global savings finance the US real estate bubble? The 'global saving glut' thesis from a stock flow consistent perspective, IMK Working Paper No 155.

Lindner, F. (2015b): Does saving increase the supply of credit? A critique of loanable funds theory, in: World Economic Review, 4, 1-26.

Michell, J. (2014a): A Steindlian account of the distribution of corporate profits and leverage: a stock-flow consistent macroeconomic model with agent-based microfoundations, PKSG Working Paper No 1412.

Michell, J. (2014b): Speculation, financial fragility and stock-flow consistency, in: Bellofiore, R., Vertova, G. (eds), The Great Recession and the Contradictions of Contemporary Capitalism, Cheltenham, UK and Northampton, MA: Edward Elgar, 112-133.

Moore, B. (1983): Unpacking the Post Keynesian black box: bank lending and the money supply, in: Journal of Post Keynesian Economics, 5(4), 537-556.

Ramanan, V., Rochon, L.-P. (2015): Reflux mechanism, in: Rochon, L.-P., Rossi, S. (eds), The Encyclopedia of Central Banking, Cheltenham, UK and Northampton, MA: Edward Elgar, 432-434.

Reissl, S. (2015): The return of black box economics: a critique of Keen on effective demand and changes in debt, IMK Working Paper No 149. 
Schmidt, J. (2011): Die Bedeutung der Saldenmechanik für die makroökonomische Theoriebildung, in: Hagemann, H., Krämer, H. (eds), Keynes 2.0: Perspektiven einer modernen keynesianischen Wirtschaftstheorie und Wirtschaftspolitik, Marburg, Germany: Metropolis, 111-147.

Schmidt, J. (2012): Sparen - Fluch oder Segen? Anmerkungen zu einem alten Problem aus Sicht der Saldenmechanik, in: Held, M., Kubon-Gilkeand, G., Sturn, R. (eds), Normative und institutionelle Grundfragen der Ökonomik, Marburg, Germany: Metropolis, 61-85.

Schmidt, J. (forthcoming): Reforming the undergraduate macroeconomics curriculum: the case for a thorough treatment of accounting relationships, in: International Journal of Pluralism and Economics Education, URL: https://goo.gl/GCMHkY.

Sinn, H.-W., Wollmershäuser, T. (2012): TARGET2 loans, current account balances and capital flows: the ECB's rescue facility, in: International Tax and Public Finance, 19(4), 468-508.

Stützel, W. (1958 [1978]): Volkswirtschaftliche Saldenmechanik, 2nd edn, Tübingen, Germany: Mohr Siebeck.

Stützel, W. (1953 [1979]): Paradoxa der Geld-und Konkurrenzwirtschaff, Aalen, Germany: Scientia Verlag.

Tarne, R. (2016): Proposals for monetary reform: a critical assessment focusing on endogenous money and balance mechanics, Paper presented at the 20th FMM conference, URL: http:// www.boeckler.de/pdf/v_2016_10_21_tarne.pdf.

Toporowski, J., Michell, J. (2012): The stock-flow consistent approach with active financial markets, in: Papadimitriou, D., Zezza, G. (eds), Contributions in Stock-flow Modeling: Essays in Honor of Wynne Godley, Basingstoke, UK: Palgrave Macmillan, 173-196.

Wicksell, K. (1898 [1936]): Interest and Prices, London: Macmillan. 